\title{
Annotations
}

\section{Solute and calorie loading in young infants: short- and long-term effects}

The short report on page 749 'Growth and Milk Intake of Normal Infants' by Evans once again raises the question of the short- and long-term effects of different forms of milk intake in early infancy. In the early 1970s attention was drawn to the consequences of high-solute milk feeding in early life, with the focus on two particular issues. (1) Did high solute feeding and its possible associated high calorie intake lead to excessive weight gain in early infancy and did this in turn result in subsequent obesity? (2) What was the effect of high-solute intake on the incidence of hypertonic dehydration?

\section{Salt and solute}

The normal salt and solute intake of a breast-fed baby is low. Breast milk on average contains about $7 \mathrm{mmol}$ sodium/litre milk. By contrast, cows' milk contains $26 \mathrm{mmol}$ sodium/litre. ${ }^{1}$ Because breast milk and cows' milk have the same caloric composition, it is inevitable that an infant fed cows' milk will take approximately 4 times as much sodium as an infant fed breast milk if an adequate caloric intake is maintained. The sodium intake of the average artificially-fed infant in Britain has thus been considerably higher than that of breast-fed babies or babies fed modified milk formulae.

The exclusive breast-fed infant has a daily salt intake of about $1 \mathrm{mmol} / \mathrm{kg}$. This contrasts with the salt intake of artificially-fed babies which is about $5 \mathrm{mmol} / \mathrm{kg}$. Infants who are exclusively breast fed increase their salt intake from $2.6 \mathrm{mmol} /$ day to $6.5 \mathrm{mmol} /$ day. Artificially-fed babies who are given solids in increasing amounts during infancy have a sodium intake rising from 9 to $60 \mathrm{mmol} /$ day. The difference between breast-fed babies given solids and bottle-fed babies is much smaller because of the high salt content in the solids. ${ }^{2}$ While the sodium intake of babies fed solids may exceed requirement by a factor of 12 or more, provided water intake is adequate, there is no difficulty in its elimination and the maximum recorded salt intake is within the safety range.

Sodium contributes only a small fraction of the osmolar load of the diet particularly when breast milk or modified formula is the main component.
Undigested milk preparations have osmolalities in the region of $300 \mathrm{mmol} / \mathrm{kg}^{3}{ }^{3}$ These values have little meaning in terms of true solute load, as the main component of this osmolality is lactose which when hydrolysed to glucose and galactose is absorbed, and when metabolised is converted to carbon dioxide and water which add nothing to the solute load. The significant osmolar load from milk comes from its sodium and other electrolytes including calcium and phosphorus, reduced approximately by that proportion which becomes part of the increasing body mass of the rapidly growing child; and from those aminoacids which are not incorporated into growing tissue and are deaminated releasing ammonia, and in the cases of cystine and methionine, sulphuric acid. Ammonia is converted to urea. To this must be added the small amount of creatinine, uric acid, and other waste products produced daily.

The addition of solids to the diet may complicate osmolar balance: (1) By increasing the overall solute load. (2) By reducing water intake as a result of the increased caloric density of food ingested.

There appear to be good physiological reasons for the low solute load of breast milk. Sodium excretion capacity matures more slowly than glomerular filtration rate and does not attain adult levels until into the second year. ${ }^{4}$ There is thus a tendency for sodium retention to occur throughout infancy, despite the fact that babies can be induced to concentrate urine to very high osmolalities. ${ }^{5}$

Babies fed cows' milk formula are more likely to develop hypernatraemia than breast-fed babies. ${ }^{6}$ An association between hypertonic dehydration and incorrect preparation of formulae has been demonstrated ${ }^{7}$ and it has been suggested that there may be a relationship between hypertonic dehydration, overconcentrated feeds, and cot deaths, as a result of observations that in half of babies dying unexpectedly the sodium concentration of the vitreous humour was raised. ${ }^{8}$

\section{Control of intake}

The factors which determine the level of intake of food may be extrinsic to the character of the food itself. The degree of physical activity and, therefore, 
of metabolism and gastric capacity are obvious examples. Osmolar/water imbalance by inducing thirst can lead to excess intake of calories while the attitude of the feeder can have a profound influence on the intake of infants. The food itself may have varying caloric density, digestibility, taste, consistency, and particle size.

Babies fed formula containing calories in excess of $2.8 \mathrm{MJ} / 1(670 \mathrm{kcal} / \mathrm{l})$ during the first 41 days of life reduce the volume of intake but still have relatively high calorie intakes when compared with infants fed a formula of conventional caloric density, suggesting a satiety threshold not yet fully effective in the very young infant. After 41 days the infant seems to regulate the volume of its intake more exactly so that the calorie intake is similar to that of infants fed standard formulae. High caloric density of food thus leads to a reduction of water intake but at least during the first 6 weeks of life to an increased caloric intake, analogous to the clinical situation of excess weight gain and risk of hypertonic dehydration as a result of overconcentrated feeds secondary to errors in preparation. ${ }^{5}$

Raising caloric density by thickening feeds may have a similar effect. Reduced intake and risk of hypertonicity would continue until at least 112 days whereas that of increased caloric intake would disappear after 42 days. Excess weight gain as a consequence of feeding formula of high caloric density would thus tend to be a phenomenon of the first 6 weeks of life. ${ }^{9}$

The mechanism of the control of intake may be via very delicate sensors which activate an hypothalamic reflex.10

\section{Effect of early weight gain}

In the early years of this decade several studies carried out in Britain showed that artificially-fed infants were tending to gain weight at rates which exceeded the centiles currently in use. ${ }^{11,12,13} \mathrm{Com}$ parison with middle-class breast-fed American babies confirmed this trend.

A study of American babies found that while the 10th centile of weight was similar for breast- and bottle-fed babies at 112 days of age, the 90 th centile was much greater for bottle-fed infants. ${ }^{14}$ These differences were ascribed to the higher caloric intake of the artificially-fed babies with early introduction of solids..$^{15}$ Other observations cast doubt on these views. It was found that while infants who were artificially fed gained weight faster than breastfed babies after age 6 weeks, this did not appear to be so in the early weeks. ${ }^{16}$

British babies during this period were being fed full-cream milk powder with added sucrose. In many parts of the country mothers were actively encouraged to introduce solids at a very early stage, a practice similar to that in current favour in the US. ${ }^{9}$ In one: study all the babies were receiving at least somes added solids by age 6 weeks, ${ }^{12}$ while an analysis of reports from most regions of Britain reveal $\bar{w}$ consistent tendency to this practice. ${ }^{17}$ Studies on the composition of formula actually produced byp mothers showed that the sodium content was high sometimes dangerously so. ${ }^{18,19,20}$

As babies tend to adjust their volume of intake tor the caloric density of the feed, the daily water intake $\vec{e}$ of babies fed overconcentrated feeds was reduced The fact that in the early weeks at least, this adjust ment is incomplete, would mean that despite reduce of water intake, calorie intake would be higher thanw that of babies fed formulae of lower calorie density ${ }^{\circ}$ The reduced water intake made infants particularlye vulnerable to changes in external water balance, an $\delta$ also made them unable to tolerate long periods without feeding, giving rise to the common complain $\vec{t}$ that the infants never seemed to be satisfied. pD Studies on serum osmolality suggested that such babies were in a state of mild hypertonicity. ${ }^{21}{ }^{22}$ The fault lay not with artificial feeding itself but ind preparation leading to solute loading and excessscaloric density. A further factor might be the wigespread use of the sucrose added to feeds simee increasing sweetness is known to raise intake. It is not surprising that in other studies where over s concentrated feeds were not used and the introduc tion of solids was delayed, there was no such tendency. ${ }^{24}$

In a study of 783 babies born in 1975-76 no excessive weight gain of bottle-fed over breast-fedB infants was shown. ${ }^{25}$ In this series however, $56 \%$ of mothers had attempted breast feeding as opposed to $25 \%$ in the 1971 Sheffield series. Furthermore only $22 \%$ of infants were receiving solids by 6 weeks of age compared with $80 \%$. The number breast fed a 6 weeks was $33.4 \%$ as opposed to $10 \%$. This study. produced results very similar to those for Sheffielde in 1974, but very different from those for the 1971-72 period (Table 1).

Since 1972-74 efforts have been made in Sheffield to encourage breast feeding, stop the early introduction of solids, and ensure that feeds are correctlyn

Table 1 Changes in pattern of infant feeding in Sheffield 1970-71, compared with other data ${ }^{25}$

\begin{tabular}{lllll}
\hline Feeding & Taitz, 1972 & Taitz, 1976 & De Swiet, 197) \\
\hline Attempted breast (\%) & 25 & 49 & 56 \\
Breast at 6 weeks (\%) & 10 & 33 & 33.4 \\
Solids at 6 weeks (\%) & 90 & 20 & 22 \\
Rate of gain & Excessive & Not excessive & Not excessive \\
Date of observations & $1970-71$ & 1974 & $1975-76$ \\
\hline
\end{tabular}


prepared $^{5}$ (M. E. Jepson, personal communication). The breast feeding rate at 6 weeks had risen from less than 10 to $33 \%$, while only $20 \%$ of infants were receiving solids at this age compared with $90 \%$. The rate of weight gain had fallen to levels comparable with those for the United States breast-fed babies and when compared with local breast-fed infants, were indistinguishable from them. ${ }^{26}$

Recent data indicate that babies who are breast fed appear to gain weight at the same rate as bottlefed babies (L. S. Taitz, unpublished, 1978), a finding confirmed in the short report on page 749.

Workers in the United States have also detected differences between breast-fed and artificially-fed babies. $^{27}$ Artificially-fed babies doubled their birthweight faster than breast-fed babies. This was associated with a tendency to introduce solids earlier in the artificially-fed group.

\section{Long-term effects}

Retrospective data indicate that babies whose weights reach the 90th centile at some time during the first 6 months of their lives are 2.6 times more likely to become obese subsequently. ${ }^{28}$ This risk of obesity was associated with infant mass but not correlated with height. The important observation in this study was that rapid weight gain in early life seemed only to presage later obesity if the actual weight gain line crossed the 75 th centile. They appear to have demonstrated that infant weight correlated with adult obesity independently of parental weight, social class, or education level which are themselves correlated with obesity.

Data from babies born at the time of the Dutch famine of the winter of 1944-45 indicate that starvation during late pregnancy and early infancy is associated with a lower incidence of obesity in later life, whereas when the famine coincided with early pregnancy then subsequent obesity was increased (Table 2). There was also a high rate of obesity among those conceived just after the end of the famine. ${ }^{29,30}$ These findings point to an important effect of early starvation in programming subsequent nutritional status one way or the other.

Some writers have questioned whether there is

Table 2 Effect of maternal starvation on incidence of obesity in progeny

\begin{tabular}{ll}
\hline Timing of famine & Incidence of obesity \\
\hline Last 3 months of pregnancy and first & \\
5 months of life & Reduced \\
Last trimester only & No effect \\
Postnatal only & No effect \\
First and second trimester & Increased obesity \\
\hline
\end{tabular}

valid evidence that infantile overfeeding may lead to subsequent obesity ${ }^{31}$ and throw doubt on the hypothesis of an early induction of obesity. A follow-up of babies previously studied ${ }^{13}$ showed that out of 203 of the 300 babies, $14 \%$ were obese and $26 \%$ overweight in infancy. By 5 years of age, these figures had fallen to 2.5 and $11 \%$ respectively. Out of 5 obese children, 3 had been obese as infants. Only one in 9 obese infants remained obese..$^{32}$ One in 3 obese infants remained overweight into childhood. The main problem with this study was the fact that there was probably a selection of children from higher socioeconomic groups, and in the light of the statement that obesity in developed countries is more common among lower social classes ${ }^{28}$ some uncertainty must surround these findings.

\section{Conclusions}

The introduction of low-solute milks in Britain would be expected to lead to a sharp decline in the incidence of hypertonic dehydration. Impressions seem to confirm this but there are no data as yet to justify the claim. There does however appear to be evidence that the excessive rates of weight gain reported in the early 1970 s may have abated with the elimination of hyperosmolar feeding. It is difficult to assess the significance of this although most paediatricians would be happier with rates of gain closer to breast-fed babies, and would for the most part come down in favour of low-solute feeds. It seems a fairly straightforward matter to recommend to mothers and teach medical students the virtues of breast feeding and modified feeds, in that order, and to follow the recommendations of the DHSS in avoiding solids until 4-5 months if possible.

That said, it is a question whether a proliferation of formulae is either necessary or desirable; we probably have more than enough already. The only really significant differences among them is their varying lipid contents. This is an area full of controversy and uncertainty, one in which the current lack of understanding makes it virtually impossible to make a rational choice, and a very good subject for some future annotation.

\section{References}

${ }^{1}$ Shaw, J. C. L., Jones, A., and Gunther, M. (1973). Mineral content of brands of milk for infant feeding. British Medical Journal, 2, 12-15.

${ }^{2}$ American Academy of Pediatrics Committee on Nutrition (1974). Salt intake and eating patterns of infants and children in relation to blood pressure. Pediatrics, 53, 115-121.

${ }^{3}$ Tomarelli, R. M. (1976). Osmolality, osmolarity, and renal solute load of infant formulas. Journal of Pediatrics, 88, 454-456. 
${ }^{4}$ Aperia, A., Broberger, O., Thodenius, K., and Zetterstrom, R. (1975). Development of renal control of salt and fluid homeostasis during the first year of life. Acta paediatrica Scandinavica, 64, 393-398.

${ }^{5}$ Taitz, L. S. (1974). Over feeding in infancy. Proceedings of the Nutrition Society, 33, 113-118.

${ }^{6}$ Kingston, M. E. (1973). Biochemical disturbances in breast fed infants with gastroenteritis and dehydration. Journal of Pediatrics, 82, 1073-1081.

${ }^{7}$ Chambers, T. L., and Steel, A. E. (1975). Concentrated milk feeds and their relation to hypernatraemia dehydration in infants. Archives of Disease in Childhood, 50, 610-615.

${ }^{8}$ Swift, P. G. F., Worthy, E., and Emery, J. L. (1974). Biochemical state of the vitreous humour of infants at necropsy. Archives of Disease in Childhood, 49, 680-685.

${ }^{9}$ Fomon, S. J. (1975). What are infants fed in the United States? Pediatrics, 56, 350-354.

${ }^{10}$ Widdowson, E. M., and McCance, P. A. (1975). New thoughts on growth. Pediatric Research, 9, 154-156.

${ }^{11}$ Hutchinson-Smith, B. (1970). The relationship between the weight of an infant and lower respiratory infection. The Medical Officer, 123, 257-262.

${ }^{12}$ Taitz, L. S. (1971). Infantile over-nutrition among artificially fed infants in the Sheffield region. British Medical Journal, 1, 315-316.

${ }^{13}$ Shukla, A., Forsyth, H. A., Anderson, C. M., and Marwah, S. M. (1972). Infantile over-nutrition in the first year of life: a field study in Dudley, Worcestershire. British Medical Journal, 4, 507-515.

${ }^{14}$ Fomon, S. J., Filer, I. J., Jr, Thomas, L. N., and Rogers, R. R. (1970). Growth and serum chemical values of normal breast fed infants. Acta paediatrica Scandinavica, Supplement 202, 1-14.

${ }^{15}$ Fomon, S. J., Thomas, L. N., Filer, L. J., Jr, Ziegler, E. E., and Leonard, M. T. (1971). Food consumption and growth of normal infants fed milk-based formulas. Acta paediatrica Scandinavica, Supplement 223.

${ }^{16}$ Ritchie, C. D., and Naismith, D. J. (1975). Comparison of growth in wholly breast fed infants and in artificially fed infants (abstract). Proceedings of the Nutrition Society, 34, 118A.

${ }^{17}$ Department of Health and Social Security (1974). Present Day Practice in Infant Feeding. Report No. 9 of a Working Party of the Panel on Child Nutrition. Committee on Medical Aspects of Food Policy. HMSO: London.

${ }^{18}$ Taitz, L. S., and Byers, H. D. (1972). High calorie osmolar feeding and hypertonic dehydration. Archives of Disease in Childhood, 47, 257-260.
${ }^{19}$ Wilkinson, P. W., Noble, T. C., Gray, G., and Spence, $\infty$ (1973). Inaccuracies in measurement of dried milk powders British Medical Journal, 2, 15-17.

${ }^{20}$ Smith, B. A. M. (1974). Feeding overstrength cows' milk to babies. British Medical Journal, 4, 741-742.

${ }^{21}$ Davies, D. P. (1973). Plasma osmolality and feeding praco tices of healthy infants in the first three months of life British Medical Journal, 2, 340-342.

${ }^{22}$ Davies, D. P., and Saunders, R. (1973). Blood urea? normal values in early infancy related to feeding practices Archives of Disease in Childhood, 48, 563-565.

${ }^{23}$ Nisbett, R. E., and Gurwitz, S. B. (1970). Weight, sex, and the eating behaviour of human newborns. Journal of Comparative and Physiological Psychology, 73, 245-253.

${ }^{24}$ Sveger, T., Lindberg, T., Weibull, B., and Olsson, U. $\mathbf{L} \vec{\omega}$ (1975). Nutrition, overnutrition and obesity in the first yea?

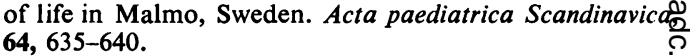

${ }^{25}$ de Swiet, M., Fayers, P., and Cooper, L. (1977). Effect óg feeding habits on weight in infancy. Lancet, 1, 892-894.

${ }^{26}$ Taitz, L. S. (1976). Relationship of infant feeding pattern to weight gain in the first weeks of life. In Pediatric an $\$$ Adolescent Endocrinology: The Adipose Child, volume 10
pp. 60-65. Edited by Z. Laron. Karger: Basel.

${ }^{27}$ Neumann, C. G., and Alpaugh, M. (1976). Birthweight doubling time: a fresh look. Pediatrics, 57, 469-473.

${ }^{28}$ Charney, E., Goodman, H. C., McBride, M. M., Lyon, B $\frac{\mathbb{D}}{\mathscr{C}}$ and Pratt, R. (1976). Childhood antecedents of aduli obesity. New England Journal of Medicine, 295, 6-9.

${ }^{29}$ Ravelli, G. P., Stein, Z. A., and Susser, M. V. (1976). Obesity in young men after famine exposure in utero and early infancy. New England Journal of Medicine, 295 349-353.

${ }^{30}$ Nutrition Review (1977). Influence of intra-uterine nutri:tional status on the development of obesity in later Nutrition Review, 35, 100-102.

${ }^{31}$ Garn, S. M. (1976). Origins of obesity. American Journal of Diseases of Children, 130, 465-467.

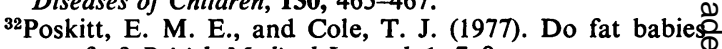
stay fat? British Medical Journal, 1, 7-9.

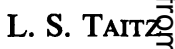

Department of Paediatrics, Children's Hospital, Western Bank Sheffield S10 2TH 